\title{
Trends in Tariff Reforms and Trends in Wage Inequality*
}

\author{
Sebastian Galiani $\uparrow$ \\ Guido G. Porto
}

\begin{abstract}
This paper provides new evidence on the impacts of trade reforms on wages and wage inequality in developing countries. While most of the vast current literature on the topic achieves identification by comparing outcomes before and after one episode of trade liberalization across industries, we propose a stronger identifying strategy. We explore the recent historical record of policy changes adopted by Argentina: from significant protection in the early 1970s, to the first episode of liberalization during the late 1970s, back to a slowdown of reforms during the 1980s, to the second episode of liberalization in the 1990s. These swings in trade policy comprise broken trends in trade reforms that we can compare with observed trends in wages and wage inequality. After setting up unusual historical data sets of trends in tariffs, trends in wages, and trends in wage inequality, our evidence supports two well-known hypotheses: trade liberalization, ceteris paribus, i) has reduced wages and ii) has increased wage inequality.
\end{abstract}

JEL CODES: F14 F16 J31

Key Words: Trade liberalization; Labor earnings; Wage inequality; Argentina

\section{World Bank Policy Research Working Paper 3905, May 2006}

The Policy Research Working Paper Series disseminates the findings of work in progress to encourage the exchange of ideas about development issues. An objective of the series is to get the findings out quickly, even if the presentations are less than fully polished. The papers carry the names of the authors and should be cited accordingly. The findings, interpretations, and conclusions expressed in this paper are entirely those of the authors. They do not necessarily represent the view of the World Bank, its Executive Directors, or the countries they represent. Policy Research Working Papers are available online at http://econ.worldbank.org.

*We wish to thank Maria Eugenia Garibotti and Mariano Negri for excellent research assistance and I. Brambilla and M. Olarreaga for comments. This paper was financed by the "Behind the Border" program of the research department of the World Bank.

†Department of Economics, Universidad de San Andrés, Argentina. Email: sgaliani@udesa.edu.ar ‡Development Research Group, Mailstop MC3-303, World Bank, 1818 H Street, Washington, D.C. 20433. Email: gporto@worldbank.org 


\section{Introduction}

There is a vast literature that studies the impacts of trade liberalization on wages and wage inequality. In Latin America, the focus of many of these papers, most of the evidence indicates that tariff liberalization has increased the disparity in labor earnings between skilled and unskilled workers. One mechanism is through the wage premia generated by tariffs in protected sectors. If protection is granted in those sectors that use unskilled labor more intensively, trade liberalization can cause relative unskilled wages to decline and wage inequality to increase. Important papers are Currie and Harrison (1997), Feliciano (2001), Galiani and Sanguinetti (2003), Goldberg and Pavcnik (2005b), Harrison and Hanson (1999), Revenga (1997), and Robertson (2004). Other mechanisms are skilled biased technical change induced by openness and skill complementarity of capital goods or imported materials. See Attanasio, Goldberg and Pavcnik (2004), Goldberg and Pavcnik (2005a), and Pavcnik (2003).

While the different papers in the literature use different techniques, identification generally follows from one episode of trade liberalization: outcomes, usually the wages of skilled and unskilled workers, are compared before and after a trade reform and across different industries so that the identifying variation hinges on the differential rate of tariff reform across sectors. Arguably, however, the estimated impacts may confound unobserved effects and unaccounted simultaneous policy reforms. This is a major concern in Latin America during the 1990s, a period when most countries implemented several concurrent reforms.

In this paper, we pursue a stronger identification strategy by exploring the recent historical record of trade policy changes adopted by Argentina during the last 30 years: from high protection in the early 1970s, to a significant liberalization of trade in the late 1970s and early 1980s, to a stagnation of tariffs in the 1980s, to the full liberalization of the 1990s, and to Mercosur. ${ }^{1}$ These swings in trade policy generate broken trends in tariff reforms that we can compare with observed trends in wage inequality. Our identification strategy thus explores a potential match between the trends in trade liberalization and the

\footnotetext{
${ }^{1}$ Mercosur, enacted in the early 1990s, is a regional trade agreement among Argentina, Brazil, Paraguay, and Uruguay.
} 
trends in wage inequality.

To develop our strategy, we set up unusual historical data sets of trends in trade reforms, trends in wages, and trends in wage inequality in Argentina. The data span the period 1974-2001. We construct a time series of tariffs, for different sectors in different years, and a time series of labor force surveys with data on individual wages. This is the first instance in this literature in which such a historical record of trade reforms is put together with a historical micro data set of workers and wages. ${ }^{2}$ The outcome is almost 30 years of data on sectoral tariffs and individual wages that, we believe, provide a different, useful, and compelling identification strategy.

In addition to exploring the overall match between trends in tariff reforms and trends in wage inequality, we use these data to compare the two liberalization episodes of the 1970s and 1990s and to examine some key differences between them. This is a contribution to the literature on trade liberalization in Latin America, which has focused almost entirely on the 1990s. However, in Argentina, both the increase in wage inequality and the trade reforms were much more marked in the 1970s than in the 1990s. The skill premium, for instance, doubled in the 1970s but increased by 42 percent in the 1990s. In addition, the average tariff reduction of the 1970s was of nearly 70 percentage points (from 100 to 30 percent) but was of 12 percentage points (from 30 to 18 percent) during the 1990s. Further, the share of wage earnings in GDP declined from 45 percent to 30 percent during the 1970s (to the benefit of the capital share), and it remained below 40 percent afterwards. It seems that an analysis based solely on data spanning the 1990s may miss important links between tariffs and wages. Here, we fill this gap by pursuing a historical investigation of these episodes of tariff reforms.

Our findings confirm that trade reforms, ceteris paribus, have i) decreased wages and ii) increased wage inequality in Argentina. After controlling for individual worker characteristics, survey effects, industry effects, and time-varying skill premium effects (like labor regulation and unionization or school quality) we find a strong positive association

\footnotetext{
${ }^{2}$ The work by Attanasio, Goldberg, and Pavcnik (2004) and Golberg and Pavcnik (2005a) is similar to ours in that it exploits data from the eighties and the nineties. There is a major difference, though. Whereas their study involves one trade reform, we study two episodes of trade liberalization separated by a reversal to protection.
} 
between tariffs and average wages, and a strong negative association between tariffs and the skill premium. Following a tariff reduction of 10 percent, for instance, the wage of an average unskilled worker would decline by 3.9 percent while the wage of an average skilled worker would decline by only 0.5 percent. This suggests that while average wages would decline, the skill premium would instead increase by 3.4 percent.

Our results suggest that tariff liberalization can help explain the decline in wages and the increase in wage inequality observed in Argentina both during the 1970s and the 1990s. There

are important differences, however. The large tariff cuts of the 1970s can account for over one fourth of the 100 percent increase in wage inequality (i.e., concretely, for 27 percentage points). During the 1990s, instead, tariff reforms can only account for 10 percent of the observed increase in wage inequality. This implies that other concurrent factors, such as other policy reforms inherent to the 1990s (technological change, deregulation, privatization), also played a key role in the determination of the wages of Argentine workers during the last decade.

The remainder of the paper is organized as follows. In Section 2, we describe the data used in this paper and we motivate our work by describing the trends in trade liberalization and the trends in wage inequality. Section 3 presents the empirical analysis and Section 4 concludes.

\section{The Trends in Tariff Reforms and Wage Inequality}

A major input into our analysis is the historical data on Argentine trade policy and wages, spanning the 1974-2001 period. These data come from two different sources: customs data on imports and tariffs, and household survey data on wages and workers.

We begin by describing the customs data. We measure trade policies with sectoral tariffs. Data on ad-valorem import tariffs come from official Tariff Schedules, which specify the tariff rate levied on each item of the Harmonized System (HS). In order to make our trade data comparable with the wage data, we need to build tariff measures at the 3-digit level of the ISIC classification. To do this, we first match each heading in the Harmonized System 
with its closest equivalent in the ISIC classification. We then aggregate the HS data to build measures of tariffs at the 3-digit level. To perform the aggregate, we start from the next-to-lowest subheading, calculate the median of the item belonging to it, and iterate on this procedure. ${ }^{3}$ We end up with a panel data set of import tariffs for the manufacturing sector across time.

Figure 1 provides some insights into the nature of trade policy and trade reform in different years. It depicts key percentiles of the distribution of import tariffs.

Figure 1 Distribution of Median Tariffs per 3 digit sector

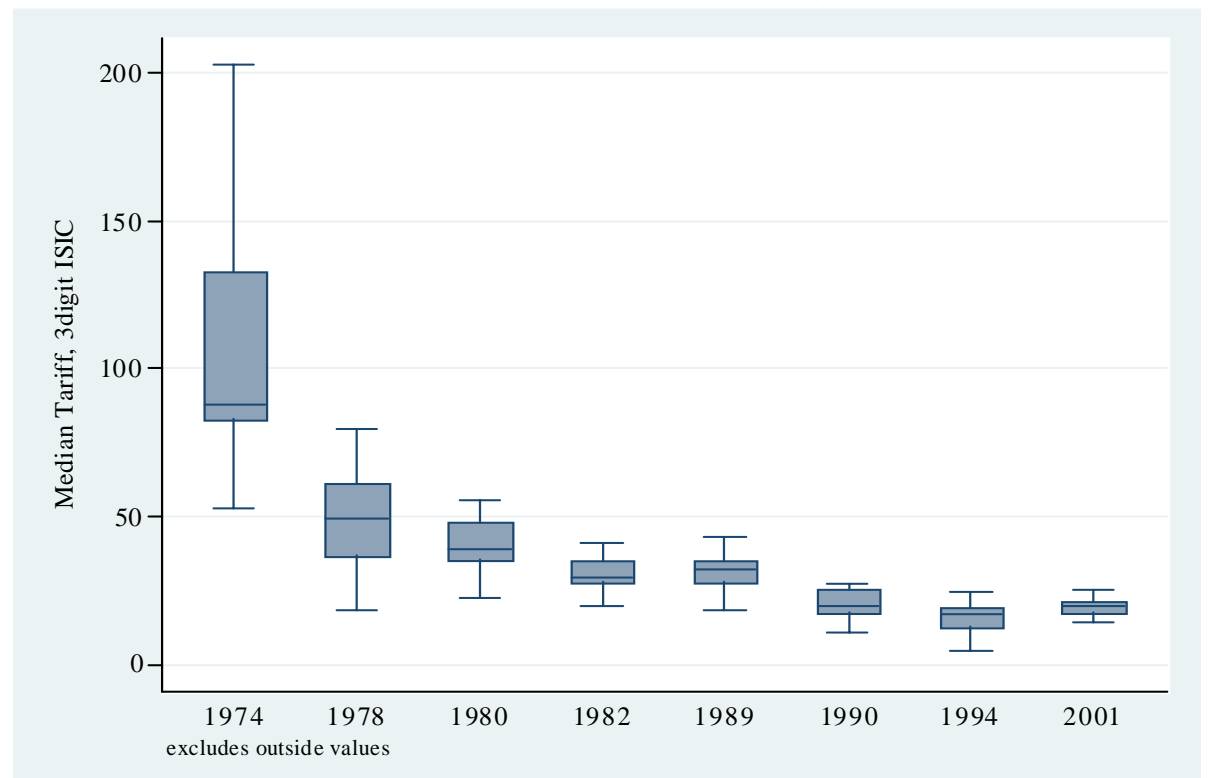

Note: Distribution of median tariff within each 3-digit ISIC manufacturing sector for selected years. The ends of the boxes are the 1st and 3rd quartiles, while the line within the boxes corresponds to the median. The ends of the bars show the points which are furthest away from the ends of the box, but at a distance not larger than $3 / 2$ the interquartile range. We do not show outside values (points which are even further away). The quantiles are calculated weighting each sector by its employment level.

The recent historical Argentine trade policy is characterized by at least three different periods. Our starting point in 1974 was one of high protection, with average tariffs in excess of 100 percent, and sectors with median tariffs in excess of 200 percent. Starting in 1976, tariffs were abruptly reduced. The average tariff was cut by two thirds in three years, dropping from slightly above 100 percent in 1976, to 47 percent in 1978 and to 32 percent

\footnotetext{
${ }^{3}$ See the Data Appendix for further details on sources of information, the matching of Harmonized System and ISIC classification, and the aggregation procedure.
} 
in 1979. In addition, the whole distribution shifted downwards with respect to 1974 . There was also a further reduction in tariffs as of 1982 .

The trend in trade reforms is broken in 1982; there was a slight increase in average tariffs starting in 1982 and continuing all throughout the eighties. In contrast, tariffs were reduced again in 1990 and 1991, remaining below 20\% throughout the decade. In 1994, Mercosur was adopted and tariffs were further reduced. However, in an attempt to prevent the fiscal crisis, there was a slight increase in tariffs in $2001 .^{4}$

We turn now to the labor force data. The standard source of individual data on labor earnings and worker characteristics in Argentina is the Permanent Household Survey (EPH, Encuesta Permanent de Hogares). This is a typical labor force survey with information on wages, employment status, and individual and family characteristics (age, gender, family size, etc.). The data are usually collected twice a year, in May and October. The labor force surveys EPHs of the 1990s have been already used in the literature but, for our purposes, we needed to track the surveys back into the 1970s and 1980s. We were able to compile $40 \mathrm{EPH}$ surveys. Table A3 in the appendix provides a brief description of the different data sets used here and their sample sizes. We have data for all years, except for 1979, 1983, and 1984. For years 1974, 1976, 1977, 1978, 1981, 1985, 1986, and 1992, we only have information for October (and thus not for May). In contrast, in 1980 and 1982, we use data on May but not on October.

To compute the skilled wage premium, we define at this stage three educational categories: skilled labor, which comprises workers who have finished college, semiskilled labor, which comprises workers who have finished secondary school (and may have incomplete college education), and unskilled labor, which comprises workers with no schooling, complete and incomplete primary education, and incomplete secondary education. The skill premium is calculated as the coefficient on the skilled dummy in a standard wage regression. Concretely,

\footnotetext{
${ }^{4}$ Trade policy is not limited to tariffs but includes non-tariff barriers like quotas, or quantitative restrictions. Unfortunately, we were unable to construct adequate measures of non-tariff barriers for the period under analysis. However, the historical accounts on the use of quotas in Argentina reveal that they were eliminated around 1959 and were not active until after 1982. Quantitative Restrictions were maintained during the eighties and were fully eliminated at the end of the 1980s as a pre-requisite to Mercosur negotiations. For more details, see Berlinski (1994) and Berlinski (2003).
} 
Figure 2 Trends in Tariffs and in Wage Premium

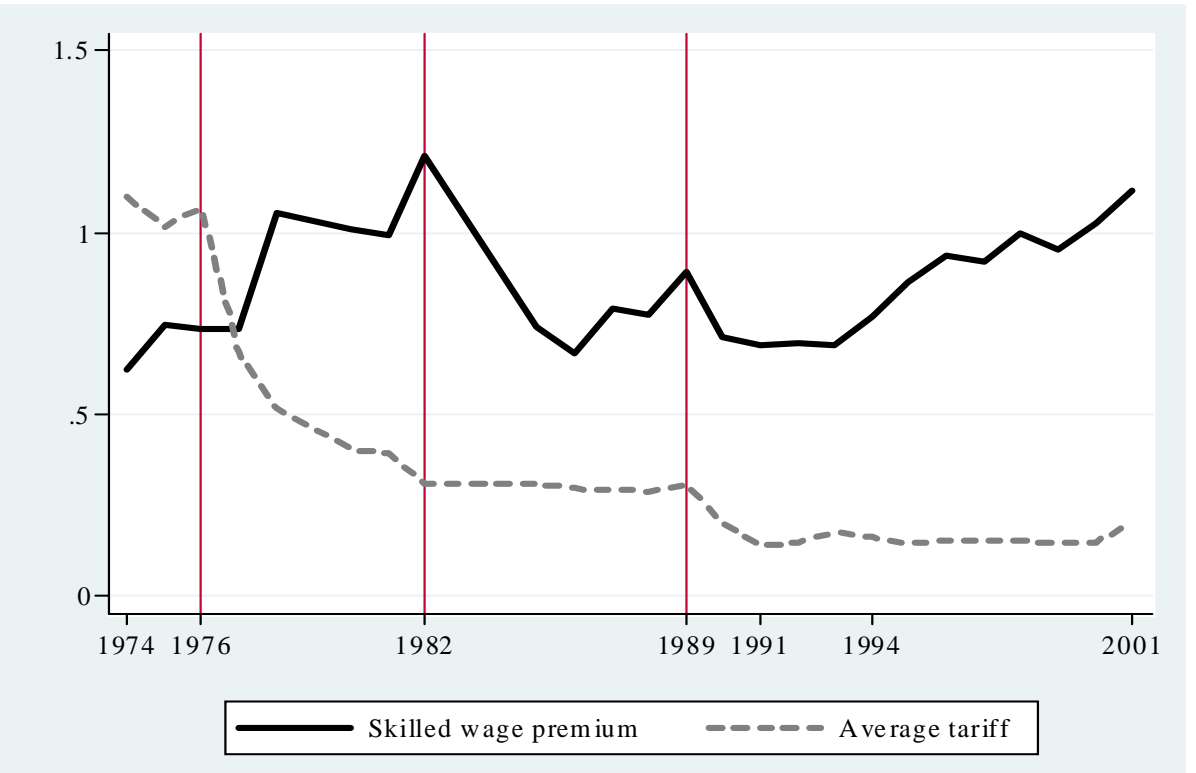

Note: own calculation based on historical trade data and labor surveys (EPH). Tariff: average tariff across all 3-digit ISIC sectors, weighted by employment in each sector. Skilled wage premium: coefficients on the skilled dummy in different earnings regressions per year.

we ran separate regressions of wages on the skill dummy for one survey in each year, controlling for age, age squared, gender and marital status. Notice that we do not include trade related variables at this point.

Figure 2 reveals the breaks in trade liberalization trends and the breaks in the wage inequality trends that we exploit in this paper. The broken line corresponds to the evolution of the average tariff during the period 1974-2001. The figure clearly shows the initial high protection on the early 1970s, the liberalization of the late 1970s, the stagnation of tariffs during the 1980s, and the last episode of liberalization of the 1990s.

The solid line in Figure 2 depicts the skill premium. ${ }^{5}$ There is a sharp increase in the differential between wages of skilled and unskilled individuals between 1974 and 1982, coinciding with the first wave of trade policy reforms. While individuals with college education earned roughly $60 \%$ more than their unskilled counterparts in 1974, the difference grew to about $120 \%$ in 1982. Between 1982 and 1989, when trade liberalization lost momentum, the skill premium decreased markedly. In contrast, the skill premium resumed

\footnotetext{
${ }^{5}$ Note that we report the estimated coefficient directly -i.e., without the standard exponential transformation $\left(e^{\text {coefficient }}-1\right)$.
} 
its upward course during the 1990s, coinciding with the second episode of trade liberalization. Overall, there seems to be a correlation between tariff levels and the skill premium. We turn next to an econometric assessment of this relationship.

\section{The Impacts of Trade}

We begin with a simple econometric model in which sectoral tariffs affect industry wages. This would be consistent with a model of interindustry wage premiums (Dickens and Katz, 1986, and Krueger and Summers, 1989) whereby wage premia are attributable to compensating differentials, specific human capital, or more generally, to unobserved worker attributes that may be systematically correlated with industry affiliation. In our model, this wage premia depend on industry tariffs.

We regress the $\log$ of the wage of individual $i$, in industry $j$, at time $t,\left(\ln w_{i j t}\right)$, on the $\log$ of the tariff in industry $j$ at time $t, \ln \tau_{t j t}$, an indicator of skill level $d S_{i g j t}$ (where $g$ indicates whether the worker is classified as skilled, semiskilled, or unskilled), and a number of other individual characteristics $\left(\mathbf{x}_{i j t}\right)$ such as age, gender, and marital status. The model is

$$
\ln w_{i j t}=\mathbf{x}_{i j t}^{\prime} \beta_{t}+\sum_{g} \delta_{g t} d S_{i g j t}+\alpha \ln \tau_{j t}+I_{j}+Y_{t}+\mu_{i j t}
$$

where $I_{j}$ is an industry fixed effect, $Y_{t}$ is a survey-period effect, and $\mu_{i j t}$ is the error term. As explained in section 2, we use data on sectoral tariffs at the 3-digit level.

We report findings from four different econometric models. In Model 1, the returns to schooling $\left(\delta_{g}\right)$ and tenure are constant across time; in Model 2, the returns to schooling are allowed to vary from survey to survey $\left(\delta_{g t}\right)$, but the returns to age are not time-varying; in Model 3, both the returns to schooling and the returns to age vary across surveys. In Model (4), we further allow for a sectoral linear trend in the model to control for possible trends in the change in wages that might be a confounding factor for the impacts of tariffs. A nice feature of our study is that the two episodes of trade liberalization that we exploit to identify the effect of tariffs on wages are separated in time by approximately a whole decade. 
This gives us enough variability to disentangle, by exploiting the within sector variability in tariffs, the effect of trade liberalization on wages from other concurrent secular trends in wages at the industry level.

In all our specifications, we include survey effects and industry dummies. This controls for changes in exchange rates (devaluations and appreciations) and industry-specific characteristics so that the impacts of tariffs are not confounded by industry characteristics or by aggregate shocks (related to policy or business cycle). These fixed effects help control for unobservable effects that would produce a spurious correlation between tariffs and wages.

Since our tariff measures vary across industries, any clustering in the residuals $\mu_{i j t}$ in (1) may be exacerbated (Moulton, 1989; Kloek, 1981). In all our regressions, thus, inference is made on the basis of a robust, cluster-corrected estimation of the variance of the error term. In all our results, we report two estimates of the standard errors. In one model, we allow for clustering at the industry level to account for autocorrelation in the residuals at the industry level (that is, for shocks to the industry that may perpetuate in time). In the second model, the errors are clustered at the time-industry level. ${ }^{6}$ Our results are robust to these two models of cluster effects.

The main results from model (1) -where we include sectoral tariffs as regressors, without interactions with the skilled dummies-are reported in Table 1. Columns (1) to (4) correspond to Models 1 to 4, respectively; the standard errors clustered at the industry level are reported within parenthesis and those clustered by industry and time, within brackets. We find a positive effect of tariffs on wages, a relationship that is significant at the 10 percent level. These results are not affected by allowing the returns to schooling to vary from survey to survey (time-varying returns to schooling in column 2) and by allowing both the returns to schooling and age to be time-varying (column 3). Further, the results remain practically unaltered if we also include sector-specific linear trends in the model (columns 4).

Our findings support the view that, ceteris paribus, trade barriers protect workers earnings across the board. ${ }^{7}$ Although these findings are more or less expected, the previous

\footnotetext{
${ }^{6}$ This is the standard clustering analyzed in Moulton (1989) and Kloek (1981).

${ }^{7}$ Since the model condition on parametric and non-parametric time trends, the correct interpretation of the negative effect of trade liberalization on wages is conditional of any growth effect of that trade reform.
} 
literature is sometimes inconclusive. In Argentina, for instance, Galiani and Sanguinetti (2003) do not find a positive association between tariffs and wages (though they do find a significant association with import penetration measures). Currie and Harrison (1997) and Harrison and Hanson (1999) are other examples where tariffs show up insignificant in wage regressions. In Attanasio, Goldberg, and Pavcnik (2004), on the other hand, tariffs have a significant impact on the industry premia and overall wages, and in Revenga (1997), real wages are also found to be affected by tariffs. ${ }^{8}$

This finding helps to explain part of the decline in the labor share of GDP that took place in Argentina during the late 1970s. Galiani and Gerchunoff (2003) report that, after the liberalization of the late 1970s, the share of labor income on GDP dropped from 45 percent to around 30 percent. Moreover, they show that this share never recovered to the historical levels observed up to the pre-seventies. The tariff elasticities reported in column (3) of Table 1, for instance, suggest that a one percent increase in the average tariff can cause average wages to increase by roughly 0.35 percent. These estimates imply that the liberalization of the 1970s, when tariffs were reduced by 70 percentage points, could have reduced wages by 24.5 percent, a decline that can account for an important fraction of the observed drop in the labor share.

\subsection{Tariff Reforms and the Skill Premium}

In this section, we examine an empirical model where tariff reforms can have an impact of the skill premium. We estimate the following model:

$$
\ln w_{i j t}=\mathbf{x}_{i j t}^{\prime} \beta_{t}+\sum_{g} \delta_{g t} d S_{i g j t}+\alpha \ln \tau_{j t}+\sum_{g} \phi_{g} d S_{i g j t} \ln \tau_{j t}+I_{j}+Y_{t}+\mu_{i j t}
$$

This model differs from (1) in that we add interaction terms between the trade policy variable (the $\log$ of tariffs, $\ln \tau)$ and the educational attainment dummies $\left(d S_{\text {igjt }}\right)$. The coefficients of these interactions, $\phi_{g}$, can be interpreted as the differential impact of trade on the wage of

\footnotetext{
${ }^{8}$ The literature on this topic is very rich. Our review of the evidence is necessarily short, to avoid distracting attention from the main results of our paper. There are very good surveys on the trade-wages link, including Goldberg and Pavcnik (2005b) and Winters, McCulloch, and McKay (2004).
} 
individuals with different education, over and above the average effect of trade protection. ${ }^{9}$

Equation (2) is consistent with a model of skill premium at the industry level as in Lovely and Richardson (2000). Consider an economy in which each firm takes the outside wage as given, but pays a premium to compensate workers for firm-specific skill acquisition or from the disutility from higher effort associated with employment in the industry. Firms are assumed to face distinct labor markets, one for each type of labor (unskilled, semi-skilled and skilled). A firm in a particular industry faces an upward-sloping supply curve for labor of each type. The elasticity of these labor supply curves is decreasing in the degree of firmor industry-specific content of human capital. In addition, the demand curve for each type of labor in a given industry is downward sloping.

Changes in trade protection arise outside the industry, from fundamental shocks like trade liberalization, and are uncorrelated with shocks to industry labor-supply curves. In particular, it may be the case that an increase in foreign competition in an industry affects unskilled workers relatively more than skilled. It may also occur that skilled workers possess less (relative) industry specific human capital, or more generally, their supply curve to an industry is more elastic than the supply curves of low-skilled workers. In both cases, which may hold true together, a shift in labor demand as a result of the trade liberalization and increased foreign competition would likely increase the premium paid to skilled workers. This is the model that we estimate next.

Our key findings are reported in Table 2. We estimate the four models described above and the two standard errors, clustered by industry (within parenthesis) and clustered by industry-time (within brackets). In the first row of the table, we show the direct impact of tariffs on average wages. We find evidence of a positive and significant effect of tariffs on the wages of unskilled labor (at the 10 percent level). The magnitudes of the coefficient range from 0.355 to 0.447 .

The second and third rows report the coefficients that show the impacts of tariff reforms on the skilled wage premium. Interestingly, we find no evidence of any impact of trade

\footnotetext{
${ }^{9}$ We also experimented with interactions of tariffs and age to explore the links between trade protection and tenure. We did not find any statistically significant association between trade policy and returns to age. See below.
} 
protection on skilled wage premiums in the model that assumes common returns to schooling and tenure across time periods (column 1). In principle, however, we should expect the skill premium to be affected across time by many factors other than trade policy (such as sectoral capital-skill complementarity, skill biased technical change or changes in sectoral labor regulations). In column (2), thus, we allow the returns to schooling to vary from survey to survey for reasons different from trade liberalization. In column (3), we further allow the returns to tenure to vary from survey to survey. In all these models, we find that trade protection affected negatively and significantly the returns to higher education. These results are robust (and remain practically unchanged) to the inclusion of sector specific linear trends (see column (4)).

Our findings confirm the intuition uncovered by Figure 2: after controlling for key confounding factors, reductions in average tariffs lead to increases in the skilled wage premium and to increases in wage inequality. These regression results appear very robust. They are not an artifact of the business cycle or spurious trends since we control for survey effects. These survey effects also control for inflation. They are not being confounded by industry characteristics due to the inclusion of industry dummies nor by industry specific trends. They are not the result of concurrent confounding policy factors, like labor reforms or industrial policies, since individual characteristics and time varying returns to age and education help control for them. Overall, thus, the results do not seem to be driven by unobservables.

Before turning to a sensitivity analysis of our findings, we provide next a quantification of the impacts of the two trade liberalization episodes underwent by Argentina. To do this, we mostly use the elasticities reported in column (3) of Table 2. The direct effect of the tariff of the wages of unskilled workers is 0.389 , which is statistically significant at the 10 percent level. Whereas the interaction with the semiskilled dummy is not significant, the coefficient of the interaction with the skilled dummy is negative $(-0.339)$ and significant at the 1 percent level. Following a 10 percent decline in tariffs across sectors, these elasticities imply a reduction in the wages of unskilled and semiskilled workers of roughly 3.89 percent but a decline in the wages of skilled workers of only 0.5 percent. 
During the liberalization of the 1970s, the average tariff was reduced by roughly 70 percentage points (from 100 percent to 30 percent). This implies a decline in the wages of unskilled/semiskilled workers of 27.2 percent and a decline of the wages of the skilled workers of only 3.5 percent. The skill premium thus rose by 23.7 percent due to this trade reform. Since during this period the observed skill premium increased by 100 percent (the coefficient of the skill dummy was 0.62 in 1974 and 1.2 in 1982), we conclude that tariff liberalization can account for about one fourth of the observed change in wage inequality.

During the liberalization of the 1990s, the average tariff was reduced from 30 percent to 18 percent, a decline of 12 percentage points. Conditional on everything else that happened at the time, this tariff reform caused a decline in the wages of unskilled/semiskilled workers of 4.7 percent, a decline in the wages of skilled workers of 0.6 percent, and an increase in the skilled premium of 4.1 percent. The skill premium increased from 0.7 in the early 1990s to 1.0 in 2000, an increase of roughly 42 percent. It follows that the second episode of trade liberalization can only account for a 10 percent of the observed increase in wage inequality.

We turn now to a sensitivity analysis. In Table 3, we reproduce the analysis of Table 2 but with a new definition of skills. Here, we classified as skill labor all workers with either a college degree or a complete secondary school degree. Unskilled workers comprise all individuals with incomplete secondary or lower education. Our findings are robust to this new definition of skills. Tariffs have a direct positive impact on unskilled wages (significant only at the 10 percent level) and a negative impact of the skill premium (significant at the 1 percent level).

There are two further concerns about the results in Table 2 that we need to address. One concern is that the association of tariffs with the skill premium in the historical data may be driven by the sharp drop in tariffs during the 1970s. Indeed, as pointed out before, the tariff cuts of the 1970s are approximately 5 times larger than the cuts of the liberalization of the 1990s. To rule out this possibility, we experimented by breaking down the historical series and dropping the 1970s from the analysis.

Our main results are reported in Table 4. The first column reproduces column (3) of Table 2, the model for 1974-2001 with three educational categories and time-varying returns 
to schooling and age. In column (2), we exclude the 1970s from the analysis. Our main findings are unaffected by this change in the sample period. Tariffs are shown to have positive effects on average wages and negative and more significant effects on the skill premium. In fact, the impacts on the skill premium are even larger when the 1970s are excluded, strongly suggesting that our results are not driven by the tariffs cuts of this period. In column (3), we exclude all years in the 1974-1982 period, where the tariff cuts were largest (Figure 2). Once again, our findings are robust to the exclusion of these years.

The second concern is the role of non-tariff barriers like quotas or quantitative restrictions. These are usual instruments of the Argentine trade policy, and provided non-tariff barriers are correlated with tariff barriers, their omission in the regressions can cast doubts on the interpretation of our key results. The problem with non-tariff barriers is that we were unable to construct historical series spanning the period under study. Even simple measures of coverage ratios are unavailable (or very hard to construct). ${ }^{10}$

In principle, if non-tariff barriers were uncorrelated with tariffs, our estimates would be consistent. However, this correlation is likely to be present, for instance if quotas are high in those industries with low tariffs. Nevertheless, using data on tariffs and non-tariff ad-valorem equivalents compiled by Kee, Nicita, and Olarreaga (2005), we found that the correlation between tariffs and non-tariff barriers in Argentina was positive but very small (around 0.03). This suggests that the omission of non-tariff barriers in the main regressions would not be a severe problem.

We follow two further strategies to account for the role played by non-tariff barriers. One way around the problem of lack of data on NTBs is to exploit the sequencing of trade reforms experienced by Argentina. Berlinski $(1994 ; 2003)$ has documented that non-tariff barriers were mostly used during the debt crisis of 1982-1989. Before that, non-tariff barriers were not generally used; after that, they were eliminated prior to the tariff cuts of the liberalization of the 1990s. This suggests a way to check the robustness of our results by further breaking down the historical series. In column (4) of Table 4, for instance, we exclude the 1982-1989

\footnotetext{
${ }^{10}$ The historical trade data that we put together in this paper does not come electronically. Instead, we had to collect hard copies of trade data for thousands of HS items for many years and to input them manually. Non-tariff barriers are usually implemented through legislative decrees specific to the different industries. Building a historical dataset of norms legislated by decrees is practically unfeasible.
} 
period from the analysis. We find that the impacts of tariffs on average wages are positive, similar in magnitude, but not statistically significant; in contrast, the impacts of tariffs on the skill premium remain negative and statistically significant.

Non-tariff barriers were fully eliminated from 1988 to 1991. Indeed, the elimination of quantitative restrictions was a pre-requisite to the negotiations of the common external tariff of Mercosur (Berlinski, 1994; 2003). Thus, an additional robustness check of the link between tariffs and the skill premium is to run the model on the 1992-2001 sample. Active trade policy during this period comprises only tariff changes. Results in column (5) confirm our previous findings. Tariffs have a positive impact on average wages; this effect is highly significant during the 1990s. Further, tariffs impact negatively, and highly significantly, on the skill premium.

A final concern with the analysis is the potential endogeneity of sectoral tariffs to wages (as in a model of political economy or unionization). In our setting, the case for the endogeneity of tariffs is relatively weak because our regressions include a number of control variables that ameliorate this problem, namely time-varying returns to schooling and tenure, individual characteristics, industry effect, time effects, and sectoral trends. The temporal variation in our data is critical to support this claim. For instance, the endogeneity of tariffs caused by sectoral unionization, industry lobbies, or political economy is unavoidable in a cross-section but can be accounted for, to a large extent, with the industry dummies, the time dummies, and the sectoral trends in the pooled historical data. Once we control for all these variables, the level of protection is mostly determined by two factors: the worldwide trend towards trade liberalization and the initial level of protection (so that sectors with higher tariffs would face larger tariff cuts, on average). ${ }^{11}$ We argue that these two factors can reasonably be thought of as exogenous to the level of current wages in our econometric models. Moreover, we claim that pursuing an instrumental variable approach would be necessarily weak given the impossibility of finding reasonable instruments due to the nature of our empirical exercise (which spans thirty years of Argentine recent history). Instead, we exploit here the comparison of the breaks in the trends in tariff reforms and the breaks in

\footnotetext{
${ }^{11}$ See Goldberg and Pavcnik (2005a)
} 
the trends in wage inequality (which are arguably exogenous). We believe that our strategy of matching sectoral tariffs to sectoral wages through two episodes or trade liberalization and one episode of reversal to protection provides a good and valid identification strategy of the effects of trade liberalization on wages and wage inequality.

To end, we use our data to ask whether trade liberalization has had an effect on the wages of young (versus more tenured) workers. This is an interesting question for it may indicate an additional channel by which trade can affect income inequality and poverty. Our findings reveal, however, that there is no evidence that trade protection has affected the experience premium; indeed, the coefficients of the interactions of trade with age (and age squared) are statistically insignificant. In the end, we conclude that trade has had an impact of the skill premium but not on the tenure premium.

\section{Conclusions}

This paper proposed to explore the links between trade liberalization and skill premium by exploring a historical dataset of Argentine trade policy and labor force surveys. To this end, we put together information spanning almost 30 years of recent Argentine history, from 1974 to 2001. This is thus one of the few cases where such a data set is constructed. A similar case is Attanasio, Goldberg, and Pavcnik (2004), who carry out an analysis covering the 1984-1998 period in Colombia. But while they explore one episode of trade liberalization (using 8 labor force surveys from 1984 to 1998), we exploit two episodes of trade reforms separated by a decade of reversion to protection (using 40 surveys from 1974 to 2001).

The 1974-2001 period under study is one of active and fluctuating trade reforms and wage inequality in Argentina. Tariff reforms accelerated in the late 1970s and early 1980s, stagnated during the 1980s, and picked up further momentum during the 1990s. The skill premium, in contrast, increased during the 1970s, declined during the 1980s, and increased

again during the 1990s. In addition, the share of labor income in GDP sharply dropped in the late 1970s, and never recovered.

We use these historical trends in tariff liberalization, in wages and in wage inequality 
to build a better and compelling identification of the impacts of trade policy on the skill premium. Overall, we find that tariff liberalization has hurt all workers but has caused an increase in the skill premium. In particular, we find that the large tariff cuts of the 1970s -of nearly 70 percentage points- can explain up to one-fourth of the observed increase in wage inequality (which doubled from 1974 to 1982). Instead, the liberalization of the 1990s -of roughly 12 percentage points- can only explain 10 percent of the increase in the skill premium (of 42 percent). This indicates that tariff reforms have contributed to the observed increase in wage inequality but that there are other concurrent factors, particularly during the reforms of the 1990s, that played a significant role too.

\section{Data Appendix}

In this Appendix we document the construction of the tariff measures used in the paper and we briefly describe the household surveys.

\section{Import Tariffs}

Our goal was to construct a measure of ad-valorem import tariffs in place in Argentina in each year during the 1974-2001 period. The source for the raw data is the Guía Práctica del Exportador e Importador, a monthly publication that provides current tariffs at the most disaggregated level of the National Import Tariff Classification (NADI). Table A1 describes the tariff definition used for different periods. Notice that these different periods are characterized by different institutional arrangements (like the adoption of Mercosur in the 1990s) and different trade related policies. For each year, we use the tariffs in place in the middle of the year.

We needed to match the tariff information from the customs sources (the Guía Práctica) with the industry data from the household survey, which is based on the ISIC industry classification. From 1974 to 1991, the Argentine Statistical Institute used the ISIC Revision 2, and moved to the Revision 3 afterwards. Hence, we matched each category in the NADI with its closest equivalent in the ISIC classification used in different period. Since the 
Table A1

Tariff Definition

\begin{tabular}{lc}
\hline \hline Time Period & Tariff Definition \\
\hline $1974-1991$ & Tariff + Statistics rate $(1)$ \\
& Extra-MERCOSUR tariff + \\
$1992-2001$ & Statistics rate + \\
& ad-valorem equivalent of DIEM $(2)+$ \\
& Convergence factor (in 2001) (3) \\
\hline \hline
\end{tabular}

Notes: (1) The Statistics rate is an additional ad-valorem levy which the government adds to certain goods. Its purpose is to finance the collection of statistical data. It was originally instituted by Executive Decree 6123/61.

(2) DIEM (Derechos de Importación Mínimos Específicos, minimum specific import taxes) originated as anti-dumping measures for certain import categories (including textiles). An "average import price" was calculated for each category, and the corresponding tariff was applied to each price. The actual tariff paid was the higher of this "minimum import levy" and the ad-valorem tariff applied to the actual price.

(3) The convergence factor was established by law in June 2001. It was calculated as $c f=1-\frac{1+e}{2}$, where $e$ is the dollar price of 1 Euro.

ISIC classification is coarser, we constructed an aggregate indicator for NADI categories corresponding to a single ISIC code. This resulted in two series - one for 1974-1991, another for 1992-2001. At a second stage, we produced a uniform classification for the whole period. Each stage is described in detail below.

Official conversion tables between 8-10 digit NADI classification and 5-digit ISIC (Revision 2) are available starting from 1980 (when 1000 new categories were added to the NADI classification). Backward compatibility with data from 1974-1979 is also possible, but at the 5-digit level of aggregation of the NADI classification. Starting in 1991, we used official conversion tables between NADI and ISIC Revision 3. Table A2 describes the sources used in this process.

Given that 5-digit ISIC is a coarser category than the NADI, we created two versions of each tariff measure. In one, we treated each NADI category as a unique observation (this is version 1 , or $v_{1}$ below). In the other one, version $2 v_{2}$, we kept one instance of each unique 5-digit ISIC/tariff combination, eliminating duplicate entries.

Once we had the 5-digit ISIC code for each NADI category, we aggregated them into 3-digit measures. Starting from the 5-digit classification, we computed the median tariff level 
Table A2

NADI-ISIC Conversion

\begin{tabular}{|c|c|c|}
\hline Time Period & Internal Classification & Source for match with ISIC \\
\hline $1974-1979$ & $\begin{array}{l}\text { Matched with new } 1980 \\
\text { classification, based on 5-digit } \\
\text { NADI }\end{array}$ & $\begin{array}{l}\text { Matched with Revision } 2 \\
\text { Categories with nonzero imports: } \\
\text { Conversion Table published by the } \\
\text { National Statistics Agency (INDEC) } \\
\text { Categories with no imports: } \\
\text { Conversion table produced by Secretaría } \\
\text { de Planeamiento (Secretary of Planning, } \\
\text { Economic Ministry) }\end{array}$ \\
\hline $1980-1991$ & $\begin{array}{l}\text { Data were kept at original } \\
\text { level of disaggregation. ( } 8- \\
\text { or 10-digit, depending on the } \\
\text { year) (1) }\end{array}$ & same as $1974-1979$ \\
\hline $1992-2001$ & $\begin{array}{l}\text { Harmonized System. Original } \\
\text { level of aggregation ( } 8 \text { digits })\end{array}$ & $\begin{array}{l}\text { Matched with Revision } 3 \\
\text { All categories: Conversion Table } \\
\text { provided by Secretaría de Industria } \\
\text { (Secretary of Industry) }\end{array}$ \\
\hline
\end{tabular}

Notes: (1) In 1980 and 1981, some tariffs are disaggregated at 8 digits, and other at 10 . In these cases, the conversion was done in two stages, starting with the 10 digit categories, and then continuing with the rest.

corresponding to each 4-digit category. To go one step further and obtain the three-digit tariff measure, we repeated this procedure. The final result is therefore the median of the medians of each subcategory.

The analysis in the main text uses $v_{2}$ as the starting point for the aggregation procedure. However, our results do not change much if we use $v_{1}$ instead. In fact their correlation coefficient between our tariff measures $v_{1}$ and $v_{2}$ is 0.954 at the three digit level. In Figure A1, we plot the time series of tariffs for nine 2-digit categories. It is clear that the series are quite similar (the correlation is 0.682 at this stage).

We used an intermediate nomenclature built by the World Bank to match the Revision 2 and Revision 3 classifications. Once again, several categories overlap and we used the median to take a representative tariff.

As a final step, we adjusted the import tariffs to take into account the differential tariff 
levied on imports originating in Mercosur countries (Brazil, Paraguay, and Uruguay). Our source for this exercise is the Commercial Liberalization Program included in the Asunción Pact (1991). This program established a progressive, automatic and linear reduction in the tariffs assigned to imports from the Mercosur countries.

First, we computed the share of the imports from the Mercosur in the year 1990, prior to the signing of the agreement. Next, we adjusted the original import tariffs considering the estimated ratio and the scales of tariff reduction established by the Asunción pact:

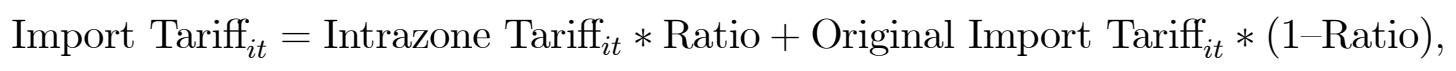

where $i$ is a 3 -digit ISIC code and $t$ is a year.

In order to provide some external consistency check on our tariff series, we compared our data with some of the indicators provided by Berlinski (1994) and Berlinski (2003). These are some of the most comprehensive accounts of the history of trade policies in Argentina. Overall, the numbers on tariff protection reported by Berlinski are quite similar to our numbers. For example, he reports that the average tariff before the liberalization of the 1970s was 99 percent (our estimate is around 100 percent). For the 1990s, Berlinski's estimates of the average tariff fluctuate around 16-19 percent, and our averages are around 18 percent. During the 1980s, he reports estimates for 1988, before the reform of the late 1980s and early 1990s, of 48 percent. We instead find that the average tariff is close to 30 percent. Even though there are differences in methodologies, mostly in aggregating the average tariffs, it is clear that our estimates are pretty consistent with those in Berlinski. It is important to remark that while Berlinski built tariff measures for selected years, in this paper we need a full time series of historical trade data. The series produced here are, we believe, an important contribution of our work.

\section{The Permanent Household Surveys}

Data on wages and worker characteristics come from the Encuesta Permanente de Hogares (EPH, Permanent Household Survey). These surveys collect information on household 
Figure A1: Comparison of Tariff Measures
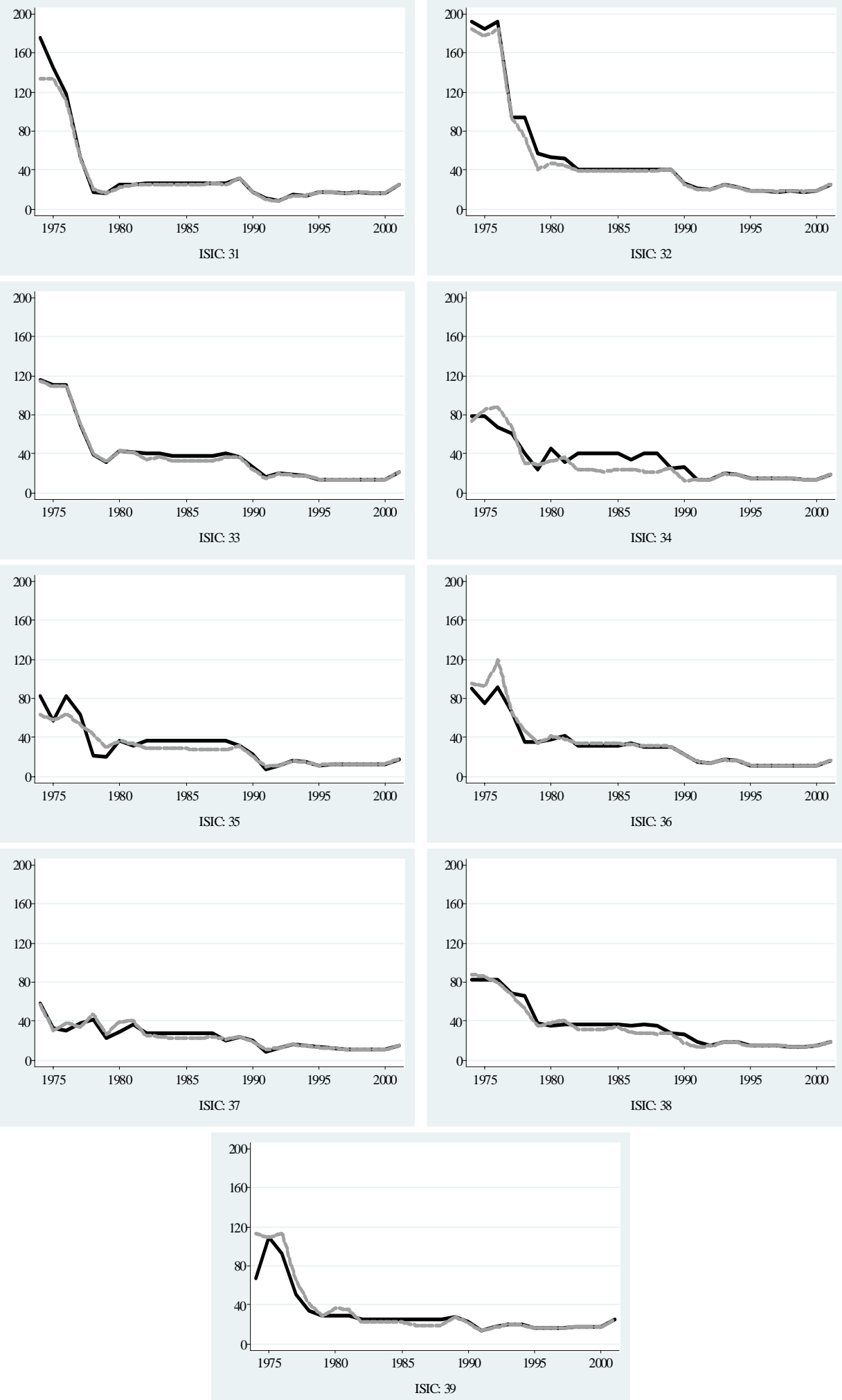

Note: Note: The dark line corresponds to version 1, $v_{1}$ (multiple observations per opening/tariff). The lighter line corresponds to version $2, v_{2}$ (one observation per unique opening/tariff combination). 
characteristics (size, composition, housing) as well as on individual characteristics like labor earning, sector of employment, hours worked, education, age, gender, marital status, etc. The EPH is a repeated cross-section and is usually collected in May and October in each year. In this paper, we pool individual data from 1974 to 2001. In Table A3, we report the different historical EPH surveys that we use and the sample sizes. For the evolution of the skill premium, see Figure 2 in the text. 
Table A3

Permanent Household Surveys Availability and Sample Sizes

\begin{tabular}{|c|c|c|}
\hline Year & May & October \\
\hline 1974 & - & 1299 \\
\hline 1975 & 1039 & 923 \\
\hline 1976 & - & 886 \\
\hline 1977 & - & 834 \\
\hline 1978 & - & 811 \\
\hline 1979 & - & - \\
\hline 1980 & 721 & - \\
\hline 1981 & - & 757 \\
\hline 1982 & 162 & - \\
\hline 1983 & - & - \\
\hline 1984 & - & - \\
\hline 1985 & - & 891 \\
\hline 1986 & - & 978 \\
\hline 1987 & 1015 & 947 \\
\hline 1988 & 1006 & 1008 \\
\hline 1989 & 988 & 932 \\
\hline 1990 & 528 & 589 \\
\hline 1991 & 1009 & 599 \\
\hline 1992 & - & 640 \\
\hline 1993 & 704 & 680 \\
\hline 1994 & 681 & 617 \\
\hline 1995 & 585 & 613 \\
\hline 1996 & 576 & 522 \\
\hline 1997 & 644 & 599 \\
\hline 1998 & 614 & 634 \\
\hline 1999 & 534 & 533 \\
\hline 2000 & 519 & 522 \\
\hline 2001 & 461 & 453 \\
\hline Total & 11786 & 17267 \\
\hline
\end{tabular}




\section{References}

Attanasio, O., P. Golberg, and N. Pavcnik (2004). "Trade Reforms and Income Inequality in Colombia," Journal of Development Economics vol. 74, pp. 331-366.

Berlinski, J. (1994). "Post Trade Liberalization Institutional Issues in Argentina," mimeo, Instituto Di Tella Working Paper No 182.

Berlinski, J. (2003). "International Trade and Commercial Policy," in A New Economic History of Argentina, Della Paollera, G. and A. Taylor (eds.), Cambridge University Press.

Currie, J., and A. Harrison (1997). "Sharing the Costs: The Impact of Trade Reforms on Capital and Labor in Morocco," Journal of Labor Economics, vol. 17, No 3, pp. S44-S71.

Dickens, W. and L. Katz (1986). "Inter-industry wage differences and industry characteristics," in Unemployment and the Structure of Labor Markets, Lang, K. and J. Leonard, (eds.), Basil Blackwell.

Feliciano, Z. (2001). "Workers and Trade Liberalization: The impact of trade reforms in Mexico on wages and employment," Industrial and Labor Relations Review, Vol. 55, No. 1, $95-115$.

Galiani, S. and P. Gerchunoff (2003). "The Labor Market," in A New Economic History of Argentina, Della Paollera, G. and A. Taylor (eds.), Cambridge University Press.

Galiani, S. and P. Sanguinetti (2003). "The impact of trade liberalization on wage inequality: Evidence from Argentina," Journal of Development Economics vol. 72, pp. 497-513.

Goldberg, P. and N. Pavcnik (2005a). "Trade, Wages, and the Political Economy of Trade Protection: Evidence from the Colombian Trade Reforms," Journal of International Economics vol. 66, pp. $75-105$.

Goldberg, P. and N. Pavcnik (2005b). "Trade, Inequality, and Poverty: What Do We Know?," prepared for the Brookings Trade Forum on Globalization, Poverty and Inequality: What Do We Know? Where Are We Going?, held in Washington DC, May 2004. 
Harrison, A. and G. Hanson (1999). "Who Gains From Trade Reforms? Some Remaining Puzzles," Journal of Development Economics, vol. 59, pp. 125-154.

Kee, H., A. Nicita, and M. Olarreaga (2005). "Estimating Trade Restrictiveness Indices," mimeo, the World Bank.

Kloek, T. (1981). "OLS Estimation in a Model Where a Microvariable is Explained by Aggregates and Contemporaneous Disturbances are Equicorrelated," Econometrica, vol. 49, No 1, pp. 205-207.

Kruger, A. and L. Summers (1989). "Efficiency wages and the inter-industry wage structure," Econometrica 56, pp. 259-93.

Lovely, M. and D. Richardson (2000). "Trade Flows and Wage Premiums: Does Who or What Matter?," in The Impact of International Trade on Wages, R. Feenstra (ed.), University of Chicago Press.

Moulton, B. (1986). "Random group effects and the precision of regression estimates," Journal of Econometrics, vol. 32, pp. 385-97.

Pavcnik, N. (2003). "What Explains Skill Upgradin in Less Developed Countries," Journal of Development Economics vol. 71, pp. 311-328.

Revenga, A. (1997). "Employment and Wage Effects of Trade Liberalization: The Case of Mexican manufacturing," Journal of Labor Economics vol. 15, pp. 520-543.

Robertson, R. (2004). "Relative Prices and Wage Inequality: Evidence From Mexico," Journal of International Economics, 64, pp. 387-409.

Winter, A., N. McCulloch, and A. McKay (2004). "Trade Liberalization and Poverty: The Evidence so Far," Journal of Economic Literature, vol XLII, pp. 72-115. 
Table 1

The Impacts of Tariffs on log Wages

\begin{tabular}{lcccc}
\hline \hline & $\begin{array}{c}\text { Model 1 } \\
(1)\end{array}$ & $\begin{array}{c}\text { Model 2 } \\
(2)\end{array}$ & $\begin{array}{c}\text { Model 3 } \\
(3)\end{array}$ & $\begin{array}{c}\text { Model 4 } \\
(4)\end{array}$ \\
\hline Log tariff & $0.357^{*}$ & $0.353^{*}$ & $0.355^{*}$ & $0.412^{*}$ \\
& $(0.203)$ & $(0.206)$ & $(0.205)$ & $(0.226)$ \\
& {$[0.215]$} & {$[0.216]$} & {$[0.216]$} & {$[0.247]$} \\
Time-varying & No & Yes & Yes & Yes \\
returns to schooling & & & & \\
Time-varying & No & No & Yes & Yes \\
returns to schooling & & & & \\
Time effects & Yes & Yes & Yes & Yes \\
$\begin{array}{lccc}\text { Industry effects } \\
\text { Sectoral Trends }\end{array}$ & Yes & Yes & Yes & Yes \\
\hline $\begin{array}{l}\text { R-squared } \\
\text { Observations }\end{array}$ & 0.89 & 0.89 & No & Yes \\
\hline \hline
\end{tabular}

Notes. Standard errors: in parentheses (clustered by 3-digit industry); in brackets (clustered by industry and time period).

The regression includes three educational categories. Skilled labor includes college graduates, semiskilled labor includes workers with secondary school and incomplete college; unskilled labor includes incomplete secondary or less.

*: Significant at 10

Other controls: age, age squared, gender dummy, head dummy, marital status. 
Table 2

Tariff Reform and the Skill Premium

\begin{tabular}{lcccc}
\hline \hline & $\begin{array}{c}\text { Model } 1 \\
(1)\end{array}$ & $\begin{array}{c}\text { Model } 2 \\
(2)\end{array}$ & $\begin{array}{c}\text { Model } 3 \\
(3)\end{array}$ & $\begin{array}{c}\text { Model } 4 \\
(4)\end{array}$ \\
\hline log Tariff & $0.355^{*}$ & $0.388^{*}$ & $0.389^{*}$ & $0.447^{*}$ \\
& $(0.200)$ & $(0.211)$ & $(0.210)$ & $(0.231)$ \\
& {$[0.213]$} & {$[0.224]$} & {$[0.224]$} & {$[0.254]$} \\
log Tariff*SemiSkilled & 0.033 & -0.077 & -0.076 & -0.082 \\
& $(0.031)$ & $(0.055)$ & $(0.056)$ & $(0.058)$ \\
& {$[0.033]$} & {$[0.053]$} & {$[0.054]$} & {$[0.054]$} \\
log Tariff*Skilled & -0.098 & $-0.355^{* * *}$ & $-0.339^{* * *}$ & $-0.345^{* * *}$ \\
& $(0.067)$ & $(0.124)$ & $(0.123)$ & $(0.121)$ \\
& {$[0.068]$} & {$[0.133]$} & {$[0.131]$} & {$[0.127]$} \\
Time-varying & No & Yes & Yes & Yes \\
returns to schooling & & & & \\
Time-varying & No & No & Yes & Yes \\
returns to schooling & & & & \\
Time effects & Yes & Yes & Yes & Yes \\
Industry effects & Yes & Yes & Yes & Yes \\
Sectoral Trends & No & No & No & Yes \\
\hline R-squared & 0.89 & 0.89 & 0.89 & 0.89 \\
Observations & 29053 & 29053 & 29053 & 29053 \\
\hline \hline
\end{tabular}

Notes. Standard errors: in parentheses (clustered by 3-digit industry); in brackets (clustered by industry and time period).

The regression includes three educational categories. Skilled labor includes college graduates, semiskilled labor includes workers with secondary school and incomplete college; unskilled labor includes incomplete secondary or less.

*: Significant at $10 \%$

**: Significant at $5 \%$

***: Significant at $1 \%$

Other controls: age, age squared, gender dummy, head dummy, marital status. 
Table 3

Tariff Reform and the Skill Premium Sensitivity to The Definition of Skilled Labor

\begin{tabular}{lcccc}
\hline \hline & $\begin{array}{c}\text { Model 1 } \\
(1)\end{array}$ & $\begin{array}{c}\text { Model 2 } \\
(2)\end{array}$ & $\begin{array}{c}\text { Model 3 } \\
(3)\end{array}$ & $\begin{array}{c}\text { Model 4 } \\
(4)\end{array}$ \\
\hline log Tariff & $0.359^{*}$ & $0.401^{*}$ & $0.402^{*}$ & $0.455^{*}$ \\
& $(0.199)$ & $(0.208)$ & $(0.207)$ & $(0.229)$ \\
& {$[0.212]$} & {$[0.223]$} & {$[0.222]$} & {$[0.253]$} \\
log Tariff*Skilled & -0.002 & $-0.158^{* * *}$ & $-0.154^{* *}$ & $-0.154^{* * *}$ \\
& $(0.033)$ & $(0.064)$ & $(0.065)$ & $(0.066)$ \\
& {$[0.035]$} & {$[0.061]$} & {$[0.062]$} & {$[0.061]$} \\
Time-varying & No & Yes & Yes & Yes \\
returns to schooling & & & & \\
Time-varying & No & No & Yes & Yes \\
returns to schooling & & & & \\
Time effects & Yes & Yes & Yes & Yes \\
Industry effects & Yes & Yes & Yes & Yes \\
Sectoral Trends & No & No & No & Yes \\
\hline R-squared & 0.89 & 0.89 & 0.89 & 0.89 \\
Observations & 29053 & 29053 & 29053 & 29053 \\
\hline \hline
\end{tabular}

Notes. Standard errors: in parentheses (clustered by 3-digit industry); in brackets (clustered by industry and time period).

The regression includes two educational categories. Skilled labor includes college and secondary school graduates, and unskilled labor includes workers with less than complete secondary school.

*: Significant at $10 \%$

**: Significant at $5 \%$

$* * *$ : Significant at $1 \%$

Other controls: age, age squared, gender dummy, head dummy, marital status. 
Table 4

Robustness Check

\begin{tabular}{lccccc}
\hline \hline & $1974-2001$ & $1978-2001$ & $1982-2001$ & $\begin{array}{c}1974-1981 \\
1990-2001\end{array}$ & $1992-2001$ \\
& $(1)$ & $(2)$ & $(3)$ & $(4)$ & $(5)$ \\
\hline log tariff & $0.389^{*}$ & $0.456^{*}$ & $0.595^{*}$ & 0.335 & $0.128^{* * *}$ \\
& $(0.210)$ & $(0.248)$ & $(0.324)$ & $(0.260)$ & $(0.054)$ \\
& {$[0.224]$} & {$[0.267]$} & {$[0.317]$} & {$[0.257]$} & {$[0.043]$} \\
log tariff*semiskilled & -0.076 & -0.088 & -0.134 & $-0.127^{* *}$ & $-0.128^{* * *}$ \\
& $(0.056)$ & $(0.072)$ & $(0.094)$ & $(0.078)$ & $(0.071)$ \\
& {$[0.054]$} & {$[0.072]$} & {$[0.083]$} & {$[0.056]$} & {$[0.049]$} \\
log tariff*skilled & $-0.339^{* * *}$ & $-0.420^{* * *}$ & $-0.487^{* * *}$ & $-0.461^{* * *}$ & $-0.442^{* * *}$ \\
& $(0.123)$ & $(0.148)$ & $(0.183)$ & $(0.142)$ & $(0.165)$ \\
Time-varying & {$[0.131]$} & {$[0.158]$} & {$[0.182]$} & {$[0.142]$} & {$[0.111]$} \\
returns to schooling & Yes & Yes & Yes & Yes & Yes \\
Time-varying & & & & & \\
returns to schooling & Yes & Yes & Yes & Yes & Yes \\
Time effects & Yes & Yes & Yes & Yes & Yes \\
Industry effects & Yes & Yes & Yes & Yes & Yes \\
\hline R-squared & 0.89 & 0.89 & 0.85 & 0.89 & 0.35 \\
Observations & 29053 & 24072 & 21783 & 21126 & 11131 \\
\hline \hline
\end{tabular}

Notes. Standard errors: in parentheses (clustered by 3-digit industry); in brackets (clustered by industry and time period).

The regression includes two educational categories. Skilled labor includes college and secondary school graduates, and unskilled labor includes workers with less than complete secondary school.

*: Significant at $10 \%$

**: Significant at $5 \%$

$* * *$ : Significant at $1 \%$

Other controls: age, age squared, gender dummy, head dummy, marital status. 